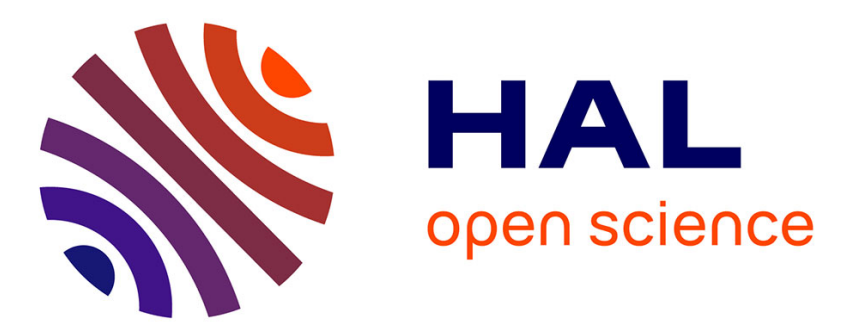

\title{
Virotia azurea (Proteaceae: Macadamieae), a striking new species endemic to New Caledonia and notes on V. francii and V. leptophylla
}

Helen C.F. Hopkins, Yohan Pillon

\section{- To cite this version:}

Helen C.F. Hopkins, Yohan Pillon. Virotia azurea (Proteaceae: Macadamieae), a striking new species endemic to New Caledonia and notes on V. francii and V. leptophylla. Candollea, 2020, 75 (1), pp.89-98. 10.15553/c2020v751a9 . hal-03128105

\section{HAL Id: hal-03128105 \\ https://hal.inrae.fr/hal-03128105}

Submitted on 2 Feb 2021

HAL is a multi-disciplinary open access archive for the deposit and dissemination of scientific research documents, whether they are published or not. The documents may come from teaching and research institutions in France or abroad, or from public or private research centers.
L'archive ouverte pluridisciplinaire HAL, est destinée au dépôt et à la diffusion de documents scientifiques de niveau recherche, publiés ou non, émanant des établissements d'enseignement et de recherche français ou étrangers, des laboratoires publics ou privés.

\section{(c)(1)}

Distributed under a Creative Commons Attribution| 4.0 International License 


\title{
Virotia azurea (Proteaceae: Macadamieae), a striking new species endemic to New Caledonia and notes on V. francii and V. leptophylla
}

\author{
Authors: Hopkins, Helen C.F., and Pillon, Yohan
}

Source: Candollea, 75(1) : 89-98

Published By: The Conservatory and Botanical Garden of the City of Geneva (CJBG)

URL: https://doi.org/10.15553/c2020v751a9

BioOne Complete (complete.BioOne.org) is a full-text database of 200 subscribed and open-access titles in the biological, ecological, and environmental sciences published by nonprofit societies, associations, museums, institutions, and presses.

Your use of this PDF, the BioOne Complete website, and all posted and associated content indicates your acceptance of BioOne's Terms of Use, available at www.bioone.org/terms-of-use.

Usage of BioOne Complete content is strictly limited to personal, educational, and non - commercial use. Commercial inquiries or rights and permissions requests should be directed to the individual publisher as copyright holder.

BioOne sees sustainable scholarly publishing as an inherently collaborative enterprise connecting authors, nonprofit publishers, academic institutions, research libraries, and research funders in the common goal of maximizing access to critical research. 


\title{
Virotia azurea (Proteaceae: Macadamieae), a striking new species endemic to New Caledonia and notes on V. francii and V. leptophylla
}

\author{
Helen C.F. Hopkins \& Yohan Pillon
}

\begin{abstract}
HOPKINS, H.C.F. \& Y. PILLON (2020). Virotia azurea (Proteaceae: Macadamieae), a striking new species endemic to New Caledonia and notes on V. francii and V. leptophylla. In English, English and French abstracts. Candollea 75: 89-98. DOI: http://dx.doi.org/10.15553/c2020v751a9

Virotia azurea H.C. Hopkins \& Pillon (Proteaceae), the seventh species in the endemic genus Virotia L.A.S. Johnson \& B.G. Briggs from New Caledonia is described and illustrated. A distribution map and preliminary conservation assessment are provided. This new species occurs principally on non-ultramafic substrates in a restricted area of central Grande Terre. It has relatively long narrow leaves, often with distally undulate-sinuate or bluntly toothed margins and a pointed apex, plus blue flowers and laterally flattened, markedly beaked fruits containing seeds with blue to mauve cotyledons. Its characters are compared with those of other species of Virotia and a key to species is provided. A handful of specimens previously identified as Virotia francii (Guillaumin) P.H. Weston \& A.R. Mast are determinated mostly as Virotia leptophylla (Guillaumin) L.A.S. Johnson \& B.G. Briggs and other species; the former is now confined to ultramafic substrates in southern Grande Terre and the latter is more widespread, principally occurring on non-ultramafic substrates though occasionally found on ultramafic ones in the south of the island as well.
\end{abstract}

\section{Résumé}

HOPKINS, H.C.F. \& Y. PILLON (2020). Virotia azurea (Proteaceae: Macadamieae), une nouvelle espèce remarquable, endémique de Nouvelle Calédonie et notes sur V. francii et V. leptophylla. En anglais, résumés anglais et français. Candollea 75: 89-98. DOI: http://dx.doi.org/10.15553/c2020v751a9

Virotia azurea H.C. Hopkins \& Pillon (Proteaceae), la septième espèce du genre endémique de Nouvelle-Calédonie Virotia L.A.S. Johnson \& B.G. Briggs, est décrite et illustrée. Une carte de répartition et son statut préliminaire de conservation sont donnés. Cette espèce est essentiellement présente sur les substrats non-ultramafiques du centre de la Grande Terre. Elle se distingue par des feuilles relativement longues et étroites, avec une marge ondulée distalement ou grossièrement dentée, et un apex pointu, des fleurs bleues, des fruits aplatis latéralement avec un bec et des graines à cotylédons bleus à mauves. Ses caractères sont comparés à ceux des espèces déjà décrites dans le genre Virotia et une clé d'indentification est fournie. Quelques spécimens précédemment identifiés comme Virotia francii (Guillaumin) P.H. Weston \& A.R. Mast sont déterminés essentiellement comme Virotia leptophylla (Guillaumin) L.A.S. Johnson \& B.G. Briggs ainsi que divers autres espèces. Virotia francii est limitée aux substrats ultramafiques du sud de la Grande Terre, alors que Virotia leptophylla est plus répandue, surtout sur des substrats non-ultramafiques, mais occasionnellement également sur des substrats ultramafiques dans le sud de l'île.

\section{Keywords}

PROTEACEAE - Virotia - New Caledonia - New Species - Taxonomy - Manganese - Serpentine flora

Addresses of the authors:

HCFH: Herbarium, Dept. Identification \& Naming, Royal Botanic Gardens, Kew, Richmond TW9 3AE, U.K. E-mail: h.fortune-hopkins@kew.org YP: LSTM, IRD, INRAE, CIRAD, Institut Agro, Université de Montpellier, Montpellier, France. 


\section{Introduction}

Virotia L.A.S. Johnson \& B.G. Briggs is a genus of Proteaceae endemic to Grande Terre, the main island of New Caledonia (Weston \& Barker, 2006; Weston, 2007). Together, Virotia, Athertonia L.A.S. Johnson \& B.G. Briggs (1 sp., NE Queensland, Australia) and Heliciopsis Sleumer (14 spp., Burma and South-Eastern China to Western Malaysia) comprise subtribe Virotiinae P.H. Weston \& N.P. Barker of the tribe Macadamieae Venk. Rao (Weston \& BAR Ker, 2006).

Virotia species are trees and shrubs that are sparsely branched or sometimes unbranched (Corner's model; BRUY, 2018) and characterised by entire, or in one species lobed, adult leaves and a lateral (or rarely terminal) conflorescence (raceme of flower-pairs). The flowers are actinomorphic and bisexual, and the four tepals curl up helically after anthesis, leaving the long, straight, narrow style projecting outwards. The hypogynous disc is annular to 4-lobed or sometimes sinuous on its upper rim and it forms a cup or collar around the base of the ovary, which contains two orthotropous ovules. The fruit is drupaceous and reported to have distinctive sculpturing on the inner mesocarp that is also seen in Athertonia and Heliciopsis (Johnson \& Briggs, 1975; Weston \& Barker, 2006; Weston, 2007).

Each flower-pair has a Y-shaped axis, subtended at the base by a small bract (Fig. 1D). The arms of this axis, immediately below the flowers, are free pedicels. VIROT (1968) regarded the stem of the $\mathrm{Y}$ as fused pedicels and the scales at the junction between the free and fused sections as bracteoles, but JoHnson \& BRIGGS (1975) considered these misnomers. They referred to the stem of the $Y$ as a peduncle (called a common peduncle by Weston, 2007) and the scales as floral bracts. However, there is no articulation at the junction between the free and "fused" parts and rarely the pedicels are free almost to the base or "fused" for their entire length.

Robert Virot (1915-2002), for whom the genus is named, was a pioneer of ecological work on the $\mathrm{New}$ Caledonian flora (see VIRot, 1956). He made numerous botanical collections in New Caledonia (Morat, 2010) and contributed two family treatments to the Flore de la Nouvelle-Calédonie et Dépendances: Proteaceae (Virot, 1968) and Epacridaceae (Virot, 1975). In his treatment of Proteaceae, he recognized six species in Macadamia F. Muell. endemic to New Caledonia. Subsequently Johnson \& BRIGGS (1975) removed several groups from within a rather broadly defined Macadamia and established the genus Virotia for these New Caledonian taxa, although they made only a single combination at the time, $V$. leptophylla (Guillaumin) L.A.S. Johnson \& B.G. Briggs; combinations for the remaining species were made subsequently by Weston \& Mast (in Mast et al., 2008). Most species of Virotia were originally described in either Kermadecia Brongn. \& Gris or Roupala Aubl., with one in Macadamia. As currently circumscribed, Macadamia comprises four species from eastern Australia
(Mast et al., 2008). The Australian M. integrifolia Maiden \& Betche, "Macadamia Nut" or "Noix de Queensland", is not native to New Caledonia but has been cultivated near Païta (e.g. MacKee [leg. Benoit] 15109, P; MacKee [leg. Boisseau] 15178 , P) (both cited as M. ternifolia F. Muell. by VIROT, 1968), Dumbéa (MacKee 8244, P) and Nouméa (Suprin 2201, P). Although Johnson \& Briggs $(1975: 102,176)$ also tentatively assigned $M$. heyana (F.M. Bailey) Sleumer from north-eastern Queensland to Virotia without formally making the combination, this species is now Catalepidia heyana (F.M. Bailey) P.H. Weston (see Weston, 1995).

We describe here a seventh species of Virotia from New Caledonia, V. azurea H.C. Hopkins \& Pillon. Three collections of this new species at $\mathrm{P}$ (MacKee 15159, 18031, 28793) bear determination slips on which Virot indicated the name Macadamia francii (Guillaumin) Sleumer ( $=$ Virotia francii (Guillaumin) P.H. Weston \& A.R. Mast) and a few additional specimens have been equated with $V$. francii by other botanists. However, only MacKee 15159 was cited in VIROT (1968) and thus contributed to the concept of $V$. francii in that revision, nearly all the remaining collections of $V$. azurea having been made after Virot's work was published. Besides excluding specimens now identified as $V$. azurea from $V$. francii, we are altering Virot's concept of the latter slightly by removing a handful of other collections which we re-determine as either $V$. leptophylla or $V$. vieillardii (Brongn. \& Gris) P.H. Weston \& A.R. Mast.

Our study was based primarily on herbarium material at $\mathrm{P}, \mathrm{NOU}$ and $\mathrm{K}$. Images for specimens at $\mathrm{P}$ are available on the website of the Muséum national d'Hisitore naturelle (P) (Sonnerat, 2020). Most latitudes and longitudes for the paratypes have been copied from their label data although in a few cases they have been taken from the Sonnerat database and are therefore cited in square brackets. The preliminary conservation assessment for $V$. azurea is based on the IUCN Red List Categories and Criteria (IUCN, 2012, 2017), using Geocat (2020; Bachman \& Moat, 2012) to calculate the Area of Occupancy (AOO) and Extent of Occurrence (EOO). In the key and in Table 1, UM = ultramafic and NUM = nonultramafic, and some regions of Grande Terre are indicated by letters representing points of the compass.

\section{Key to the species of Virotia}

1. Leaves associated with flowers and fruits usually 3-5-lobed (NUM, central) V.rousselii

1a. Leaves associated with flowers and fruits simple ........ 2

2. Higher order venation comprising well developed, regularly shaped areoles; leaf blades in adult plants elliptic or obovate ............................................................. 3

2a. Higher order venation forming areoles less regular in shape and arrangement; leaf blades in adult plants oblanceolate, narrowly ovate-elliptic, or sometimes elliptic 


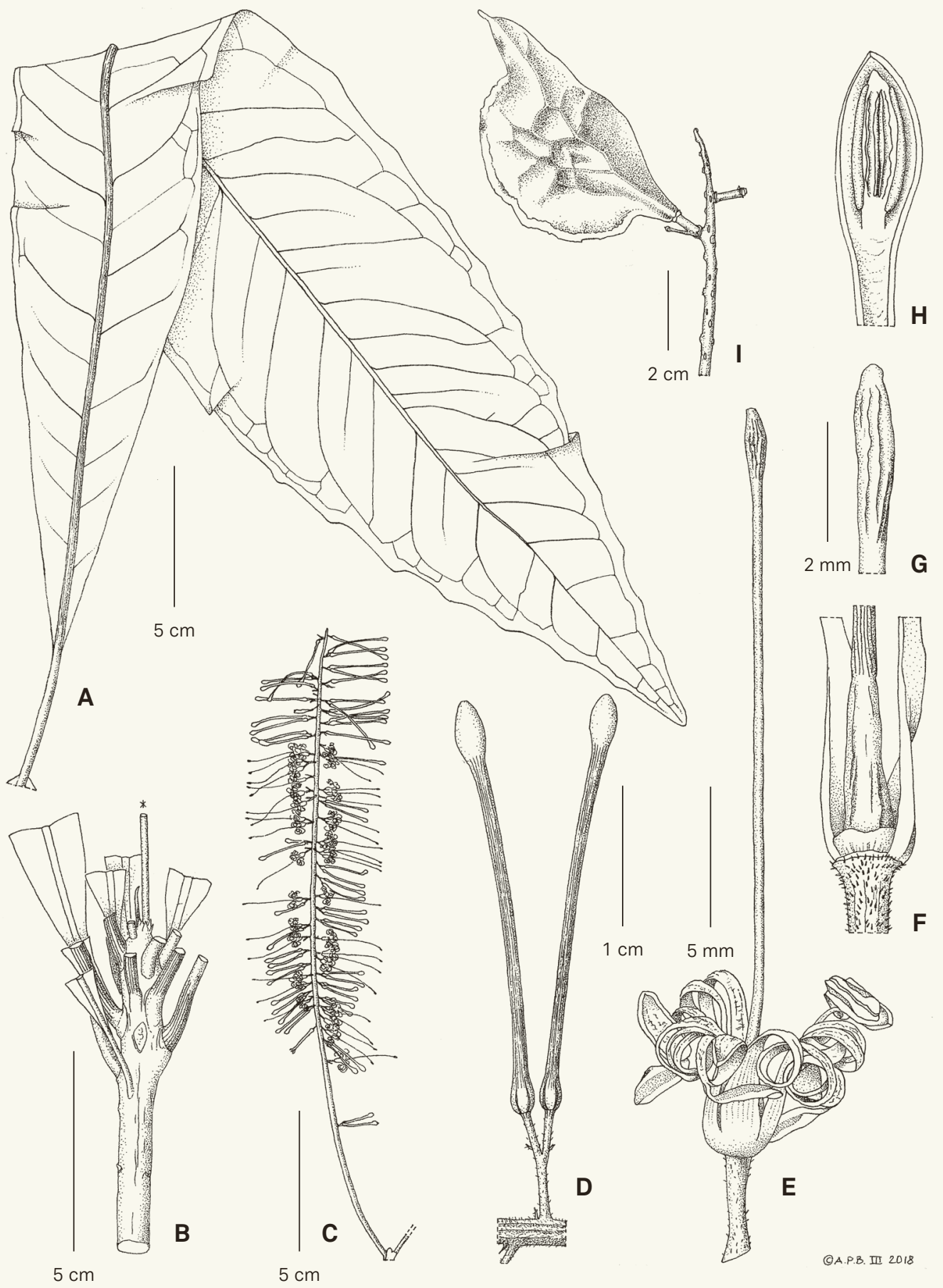

Fig. 1. - Virotia azurea H.C. Hopkins \& Pillon. A. Leaf; B. Apex of a shoot showing the arrangement of leaf bases and the base of an inflorescence axis (*); C. Inflorescence (conflorescence), the flowers post-anthesis; D. A flower-pair immediately prior to anthesis, their peduncle subtended by a minute bract and a small bract present at the base of each pedicel; E. A flower post anthesis, the tepals all helically curled;

F. Base of a flower, two tepals removed to show the ovary and the cup-like disc around it; G. Apex of the style, slightly swollen and ridged, forming the pollen presenter; H. Distal part of a tepal, inner surface, with the anther attached; I. Immature fruit, note prominent beak.

[A, C, E-H: Gâteblé et al. 87, P; B: Munzinger et al. 1462, P; D: MacKee 15159, P; I: MacKee 46274, P] [Drawing: Andrew Brown] 
3. Leaf blades in adult plants obovate or elliptic, $5-11 \times 2.2-5.5 \mathrm{~cm}$, narrowly cuneate at the base, drying mid brown and noticeably paler than the petiole; secondary veins relatively few (7-15 on either side of midrib fide VIROT, 1968), at a narrow angle to the midrib $\left(30-40^{\circ}\right)$; inflorescence axis, pedicels and outer surface of tepals glabrous (UM, S)

V. neurophylla

3a. Leaf blades in adult plants elliptic, $12-20.5 \times 4-5.5 \mathrm{~cm}$, rounded or broadly cuneate at the base, drying dark greenbrown and not noticeably paler than the petiole; secondary veins more numerous $(18-35$ on either side of midrib fide Virot, 1968), at a wider angle to the midrib $\left(\right.$ c. $\left.60^{\circ}\right)$; inflorescence axis, pedicels and outer surface of tepals with small, adpressed, reddish hairs (NUM, NE) .......... V. vieillardii

4. Secondary veins anastomosing close to the leaf margins, forming an intramarginal vein along the entire length of the leaf (UM, S)

V. francii

4a. Secondary veins not anastomosing close to the leaf margins in distal part of leaf, intramarginal vein either absent or present towards the base of the blade only .... 5

5. Leaves long-attenuate at the base and sessile or almost so; inflorescence usually short (6-17.5 cm long); tepals bright pink (UM, NW only, Tiébaghi and environs)

V. angustifolia

5a. Leaves cuneate or narrowly cuneate at the base and petiolate, though sometimes shortly so (petiole $>1 \mathrm{~cm}$ ); inflorescences often longer $(9-33 \mathrm{~cm})$; tepals white, pale yellow, blue, pale pink or purplish white (mostly NUM, not NW) ... 6

6. Leaf blades $30-56 \mathrm{~cm}$ long, the margins often bluntly toothed distally, and the apex usually pointed or sometimes obtuse; fruits crescent-shaped to \pm elliptic in outline with a marked, sometimes sharply pointed beak (NUM or rarely UM, central)

V. azurea

6a. Leaf blades $7.5-22.5 \mathrm{~cm}$ long, the margins entire or sometimes minutely irregular, and the apex obtuse; fruits almost circular in outline, apex unbeaked or umbonate at most (NUM, central or UM, S)

V. leptophylla

\section{Taxonomic treatment}

Virotia azurea H.C. Hopkins \& Pillon, sp. nov. (Fig. 1-3).

Holotypus: New Caledonia. Prov. Nord: PoindimiéAmoa, Wabuli, 2057'26"S 16514'24"E, 23 m, 6.II.2013, fl., Gâteblé et al. 87 (P [P01067947]!; iso-: NOU!).

Virotia azurea H.C. Hopkins E Pillon is similar to V. leptophylla (Guillaumin) L.A.S. Johnson E B. G. Briggs but differs by its longer, oblanceolate leaves that often have a rather long, pointed apex and margins that are often bluntly toothed distally (beyond the widest point), and by the fruits that in lateral view are crescent-shape or elliptic and strongly beaked.
Slender, single- or multi-stemmed shrub or small tree 3-6 m high, following Corner's model of architecture, sometimes with many iterations (D. Bruy, pers. comm.). Leaf-bearing stems circular in cross-section, $9-10.5 \mathrm{~mm}$ diam., with some minute hairs. Older stems with \pm circular or kidney-shaped leaf-scars, the bark rough with numerous pale lenticels. Leaves in juvenile plants (seedlings, later stages of juvenile growth and regrowth shoots) not known. Leaves in adult plants spirally arranged, the distal ones clustered around the shoot apex, simple, shortly petiolate, erect to spreading; petioles $1.5-3(-7) \mathrm{cm}$ long, fairly stout $(3 \mathrm{~mm}$ diam.), terete; blades oblanceolate, $30-56 \times 5.3-11.5 \mathrm{~cm}$; base narrowly cuneate or sometimes decurrent, symmetric; apex acute, pointed with a rounded tip, or bluntly pointed to \pm rounded; margins usually somewhat undulate and sinuate to bluntly toothed, occasionally \pm flat and entire; both surfaces entirely glabrous or almost so (a few minute hairs at most on midrib and on lower surface, at $\times 40$ ), dark shiny green above and lighter beneath; midrib on upper surface slightly indented to slightly raised towards the base, prominent, rounded and longitudinally ridged beneath; secondary and higher order venation minutely prominent on both surfaces in dry material; towards the base of the blade, secondary veins at a wide angle $\left(\right.$ c. $\left.60-70^{\circ}\right)$ to the midrib, parallel to one another and linked by an intramarginal vein close to the margins; in the middle and distal part of the leaf, secondary veins gradually at a narrower angle to the midrib (c. $40-60^{\circ}$ near the apex), either parallel or arcuate, branching and anastomosing further from the margins. Inflorescences: axes either inserted either singly in a leaf axil or 1-2 apparently arising from the axil of a leaf scar proximal to the current leaves (or rarely terminal, in Munzinger et al. 1462), erect or spreading; each a raceme of flower-pairs of total length $14-26 \mathrm{~cm}$, including a common peduncle $7-9 \mathrm{~cm}$ long and bearing a few widely spaced bracts each to $3 \mathrm{~mm}$ long; flowering part cylindrical, $5.5-8 \mathrm{~cm}$ diam., its central axis slender, $1-2 \mathrm{~mm}$ diam., slightly ridged longitudinally, quite densely hairy when young, later sparsely to moderately hairy (at $\times 40)$, the hairs short, red-brown, adpressed. Flowers: in pairs, the axis of each pair arising in the axil of a small, minutely hairy bract $0.5 \mathrm{~mm}$ long. Peduncle of each flowerpair 1.5-5 mm long, bearing 2 pedicels each (0-)1-4 mm long, peduncle and pedicels together 3-9 $\mathrm{mm}$ long, slender, minutely hairy, slightly ridged longitudinally; bracts inserted close to the base of the pedicels (or sometimes below, on the peduncle), minute, triangular, $0.5 \times 0.2 \mathrm{~mm}$, hairy; hairs on peduncles, pedicels and bracts $0.1 \mathrm{~mm}$, reddish, adpressed. Bud just prior to anthesis a straight slender tube (20-)25-32 mm long, very narrow for most of its length, expanded into an ovoid at the tip, also slightly expanded at the base, blue; outer surface sparsely to moderately hairy (hairs minute, reddish, adpressed). Tepals post-anthesis splitting to or almost to the base (remaining united at the base for up to $3 \mathrm{~mm}$ ), tips of 

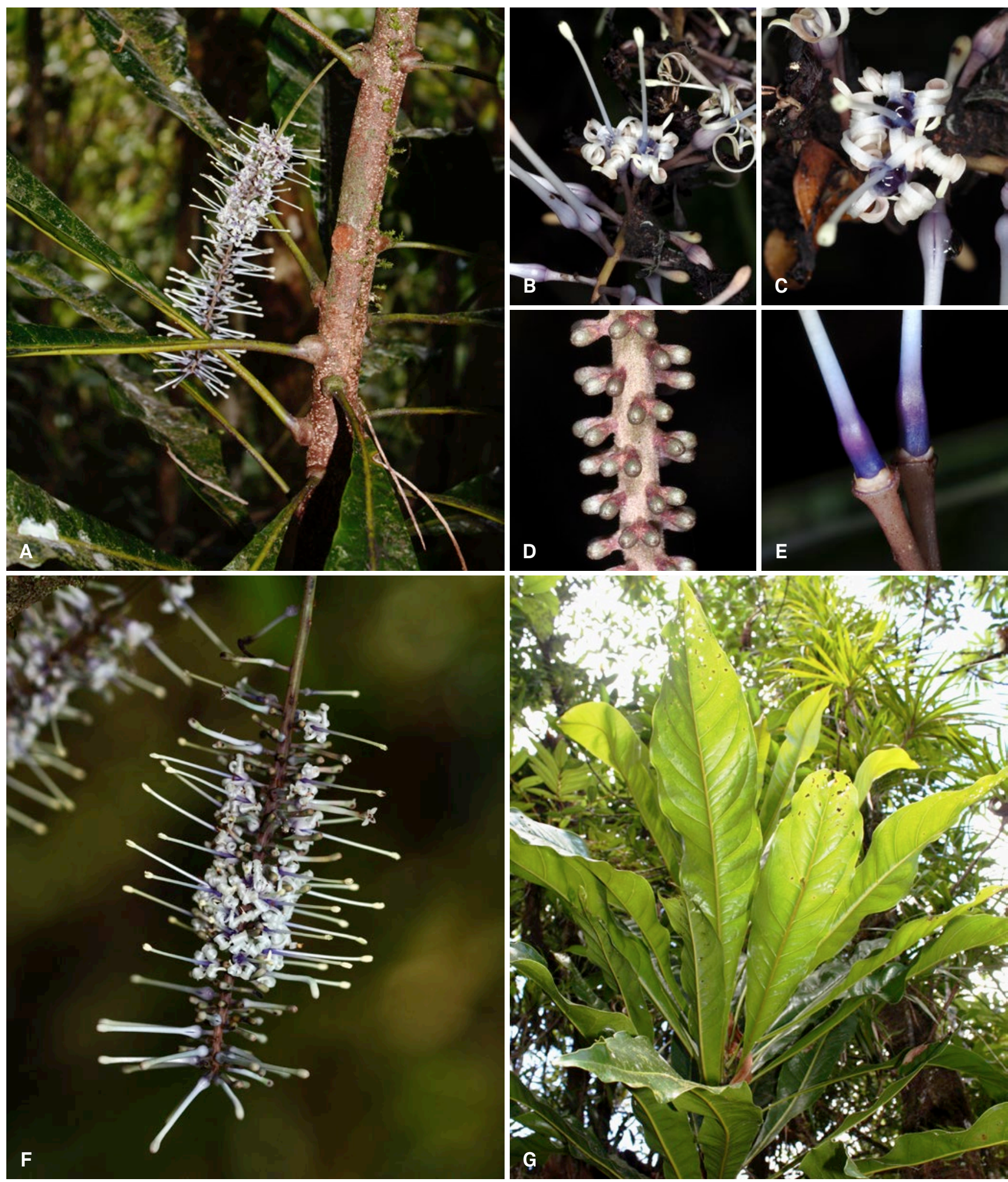

Fig. 2. - Virotia azurea H.C. Hopkins \& Pillon. A. Inflorescence arising from a leaf axil; B. A flower-pair at anthesis plus flower buds;

C. Pair of flowers (note helically curled tepals and nectar); D. Very young floral buds; E. Two purple ovaries (note disc at base) and white styles;

F. Inflorescence; $\mathbf{G}$. Under surface of foliage.

[Photos: A, F-G: G. Gâteblé; B-E: C. Laudereau] 

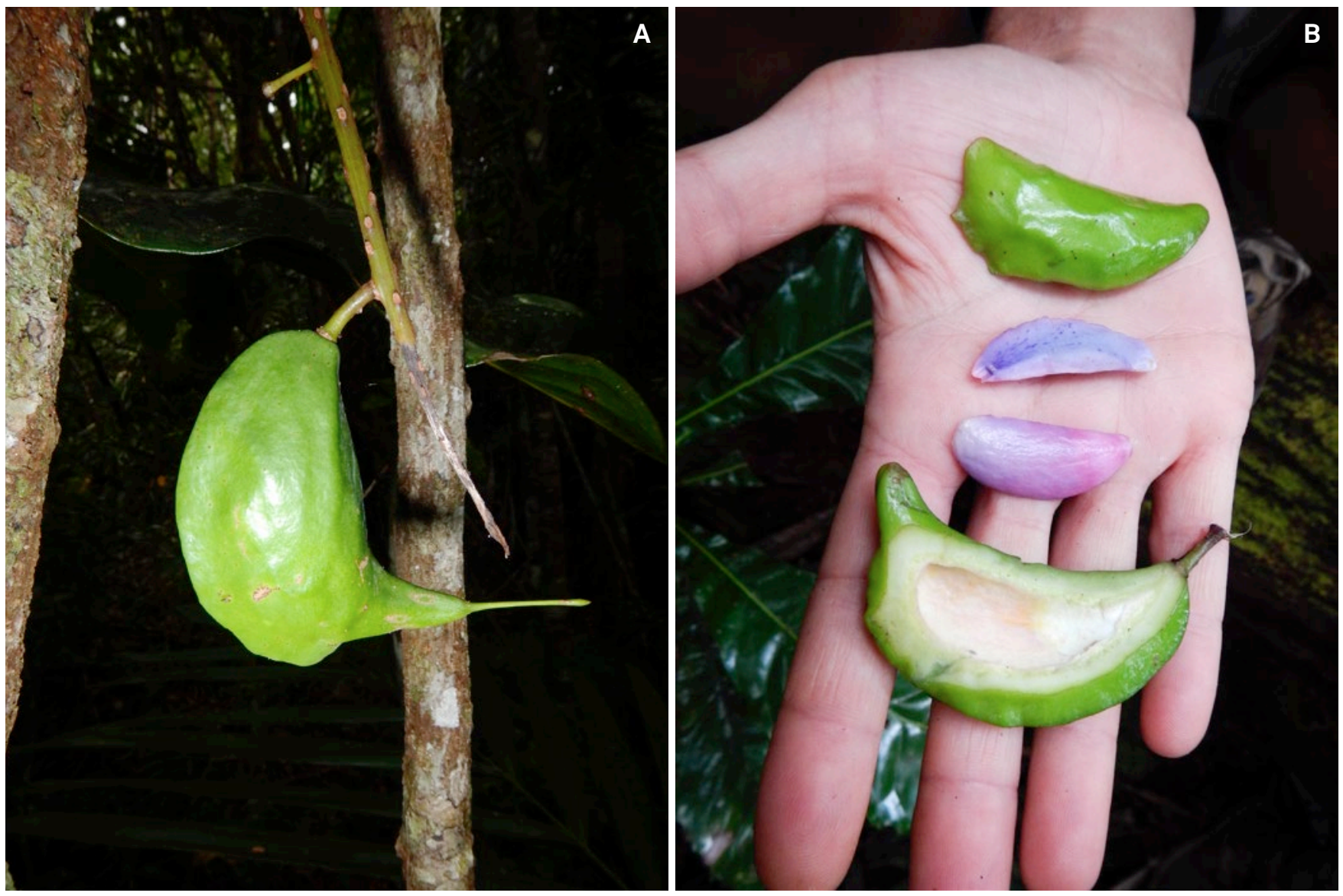

Fig. 3. - Virotia azurea H.C. Hopkins \& Pillon. A. Fruit; B. Fruit cut open to reveal the bluish mauve cotyledons.

[Photos: G. Gâteblé]

lobes ovate, thickened, $2.5 \times 1.5 \mathrm{~mm}$, tepal lobes below the tip long and narrow, curling helically, blue to white (including light blue, mid-blue and white-violet), their inner surface glabrous. Stamens: free part of the filament very short, each one inserted towards the base of the ovate tip of a tepal; anthers $2 \times 1 \mathrm{~mm}$, the connective shortly prolonged at the apex. Disc an erect, hypogynous cup or collar, thin, glabrous, slightly undulate along the top margin to shallowly 4-lobed or the lobes sometimes splitting to the base, maximum height $0.4 \mathrm{~mm}$. Gynoecium: ovary cylindrical-conical, $1.5-2.5 \times 0.8 \mathrm{~mm}$, glabrous or with a few minute hairs, blue or violet; style cylindrical, long and slender, $21-30 \times 0.5 \mathrm{~mm}$, glabrous, \pm white, the distal $2.5 \mathrm{~mm}$ forming a slightly swollen pollen presenter, this glabrous and shiny black with longitudinal ridges when dry; stigma a short terminal slit. Fruit few per infructescence, each borne on a thickened pedicel/peduncle c. $8 \mathrm{~mm}$ long, somewhat laterally compressed, crescent shaped or ventral part \pm elliptic in outline with a marked beak at the end of the dorsal margin, c. $7.3 \mathrm{~cm}$ long (including the beak $1.5 \mathrm{~cm}$ long) $\times 3.5 \mathrm{~cm}$ deep (between the mid-points of the ventral and dorsal margins); epicarp bright or dark shiny green, glabrous; seed (based on Gâteblé et al. 449) 1 per fruit, almond-shaped, c. $4 \mathrm{~cm}$ long $\times 1.7 \mathrm{~cm}$ wide, cotyledons pale blue to mauve or pale violet.

Etymology. - The epithet, azurea, describes the colour of the flowers. According to StEARN (1992: 241), azureus means sky-blue, a light, pure, lively blue. Fresh seeds have cotyledons that are also bluish, tinged with pale violet.

Distribution, habitat and phenology. - Virotia azurea is found in a restricted area of central Grande Terre that extends from Mt Aoupinié in the south to Povila in the north (Fig. 4), growing in humid forest at altitudes between 20 and $600 \mathrm{~m}$. Most collections are from non-ultramafic substrates; the type, Gatêble et al. 87, is an exception as the field notes indicate the substrate as ultramafic. This reflects the geology of the area which is largely non-ultramafic but with pockets of ultramafic, especially serpentinite. One explanation for these small pockets or "filons" of ultramafic rock in otherwise non-ultramafic regions is that they may be due to diapirism (solid injection) along fault planes, in contrast to the large regions of ultramafics in the south and along the west coast of Grande Terre, in which over-thrust has been significant (Lillie \& Brothers, 1970). 


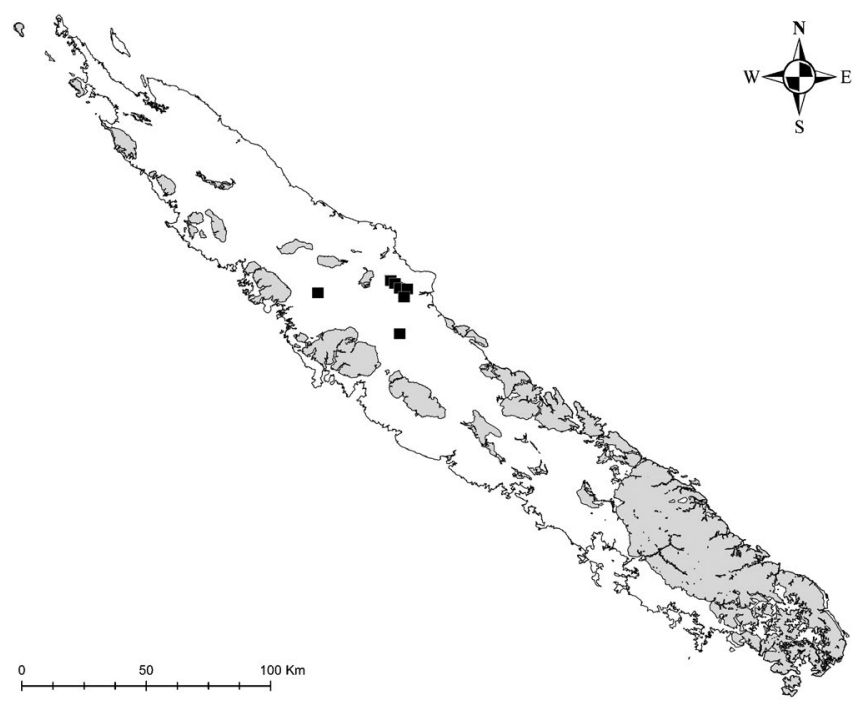

Fig. 4. - Distribution of Virotia azurea H.C. Hopkins \& Pillon in New Caledonia. Areas with ultramafic substrate are shown in grey.

Mature flowers and large floral buds have been collected in February, April, June and October-November, and fruits in November-December and April.

Conservation status. - Most collections of the new species were made in the adjacent valleys and ridges of Amoa and Tchamba, where it can be locally abundant (see field notes of Bruy 1220). Other localities where it has been collected are Povila, plateau de Tango and Mount Aoupinié. Its habitat, rainforest, is relatively well-preserved in this part of New Caledonia. While Mount Aoupinié is a nature reserve, plateau de Tango has been heavily planted with the invasive tree Pinus caribaea Morelet. Dispersal of this large-fruited, large-seeded new species may be problematic because of hunting pressure on its putative dispersers (flying foxes and New Caledonian Imperial Pigeons). Virotia azurea was evaluated by the New Caledonia Red List Authority at a workshop held in Thio on October 24th 2019. It qualifies as "Vulnerable" [VU B1ab(iii,v)+2ab(iii,v)] under the IUCN Red List Categories and Criteria (IUCN 2012, 2017), based on an estimated AOO of $32 \mathrm{~km}^{2}$, an EOO of $578 \mathrm{~km}^{2}$ and its occurrence at six localities.

Notes. - Virotia azurea is similar to V. leptophylla but differs by its longer, oblanceolate leaves $(30-56 \mathrm{~cm}$ long vs $7.5-22.5 \mathrm{~cm}$ in $V$. leptophylla) that often have a rather long, pointed apex, and margins that are often bluntly toothed distally (beyond the widest point) (vs apex usually obtuse or rounded and retuse, and margins entire or sometimes minutely irregular), and by the fruits that in lateral view are crescent-shape or elliptic and strongly beaked (vs fruit \pm circular in lateral view and slightly umbonate at most) (Table 1). Although the leaf margins in both species can be sinuous-undulate, this character is more commonly seen in V.azurea.

Both species occur in forest at similar elevations in central Grande Terre, principally on non-ultramafic substrates. However, at present, few, if any, collections of $V$. leptophylla are known from the exact region where $V$. azurea has been collected. Virotia azurea is compared with other species of Virotia in Table 1.

Some material of Virotia azurea was previously identified as $V$. francii. These two species are not sympatric and morphologically, $V$. francii can be distinguished by its leaves, which typically have shorter blades, usually borne on longer petioles, and they have an intramarginal vein that extends along the entire length of the leaf (see below). Both $V$. leptophylla and $V$. francii usually have cream-white to pale yellow flowers, although rarely both have been reported to have some pink, lilac, violet or blue on the tepals (e.g. MacKee 12654 (P), V. leptophylla).

Fig. 3B shows two bluish-mauve, naked cotyledons from a seed of $V$. azurea. Cotyledons pigmented with anthocyanin are also known to occur in $V$. neurophylla (Guillaumin) P.H. Weston \& A.R. Mast (cotyledons of recently germinated seedlings deep purple-maroon on both inner and outer surfaces) and $V$. francii (cotyledons deep purple on the abaxial surface and plain green on the adaxial one) (P. Weston, pers. comm.).

The species that is most commonly sympatric with V. azurea, also occurring in the region from Povila and Haute Tchamba-Haute Amoa southwards to Mt Aoupinié, is $V$. rousselii (Vieill.) P.H. Weston \& A.R. Mast. This is usually readily distinguished by the large, robust 3-5-lobed leaves that accompany the flowers and fruits. In rare instances where the leaves associated with reproductive structures are simple or only partially lobed, as in MacKee 13139 (P, K) the blades are broadly oblanceolate and broadly rounded at the apex, and the inflorescence is longer, broader and more robust than in V. azurea.

The long, oblanceolate leaves of $V$. azurea are rather similar to those of $V$. angustifolia (Virot) P.H. Weston \& A.R. Mast, which is restricted to ultramafic substrates on and around the Massif de Tiébaghi in north-western Grande Terre. However, the leaf blades of $V$. angustifolia are long-attenuate at the base, typically lacking a petiole, and the margins are entire though they can be undulate. In addition, $V$. angustifolia commonly has rather short inflorescences, $6-17.5 \mathrm{~cm}$ long, and the flowers are bright pink, not blue or bluish.

In most herbarium specimens of Virotia azurea, the leaves are either detached from the stem or attached to only a short section of it, and the inflorescences appear either to arise in the axil of a fully developed leaf or, when described in field notes as borne on the stems or branches, presumably they arise in the axil of a leaf scar. However, in Munzinger et al. 1462, we have the apex of a stem with the leaves clustered around it (Fig. 1B) 


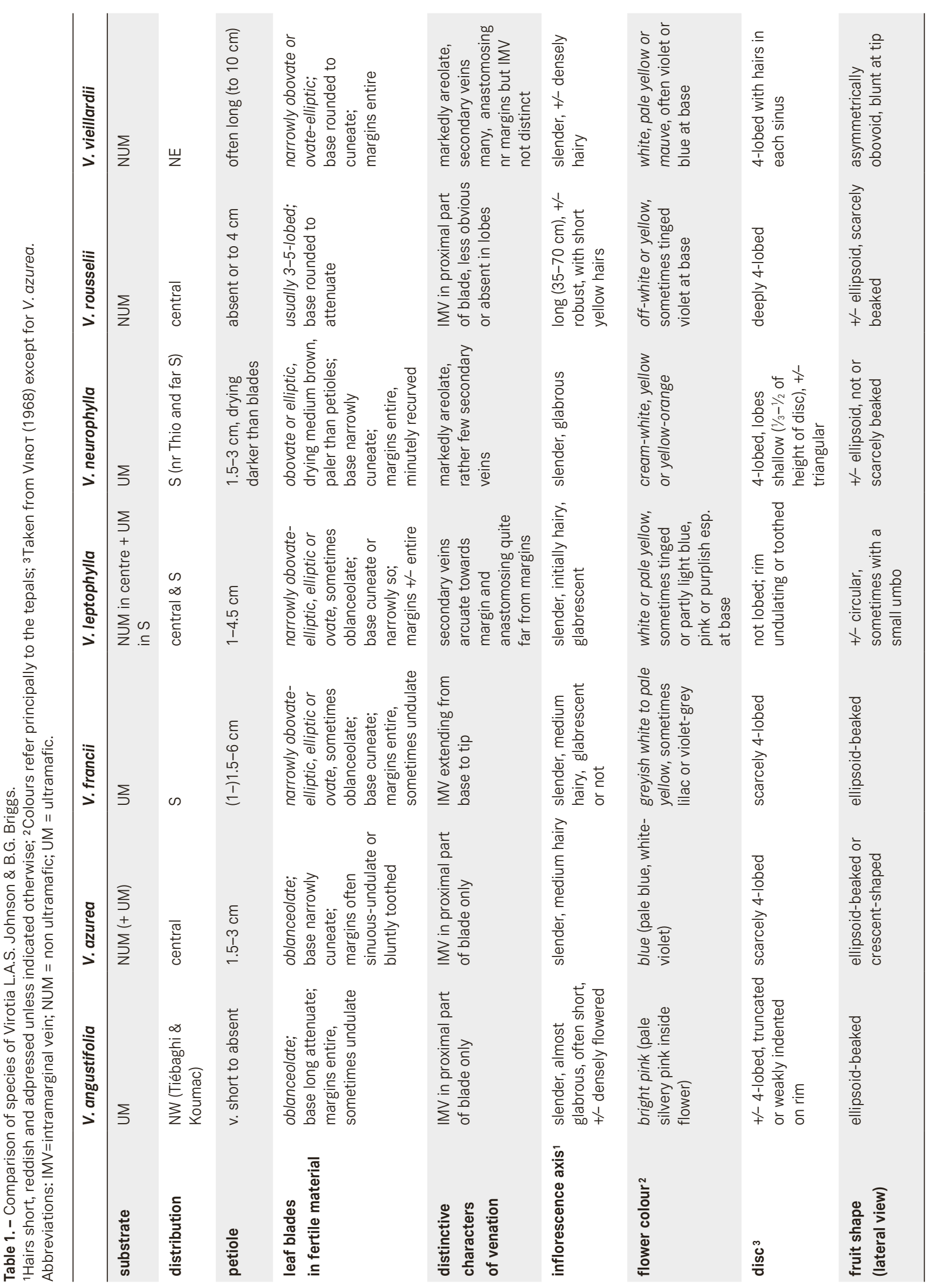


and the peduncle of a young inflorescence arising at the tip of this stem. The leaves could be loosely described as forming a "terminal cluster" but they do not terminate the growth of the stem and so are not truly terminal, whereas the inflorescence does appear to terminate the shoot. The peduncle has a series of small, triangular, adpressed bracts around the base and at intervals along its length.

Leaf manganese content was measured non-destructively on Virotia azurea's herbarium specimens with a handheld X-Ray Fluorescence (XRF) spectrometer (JAFFRÉ et al., 2013; VAN DER ENT et al., 2019). We found significant variations with a high value of $4178 \mu \mathrm{g} \mathrm{g}^{-1}$ for Gâteblé et al. 87, and lower values for other specimens: $819 \mu \mathrm{g} \mathrm{g}^{-1}$ (MacKee 4651), 825 (MacKee 18031), 981 (Munzinger et al. 1462), and a value below the detection threshold for Veillon 4651. The accumulation of manganese is a typical characteristic of New Caledonian Proteaceae growing on ultramafic substrates (JAFFRE, 1979), and these measurements are consistent with the dual ecology of this species, occurring on both serpentine and other metamorphic substrates.

Vieillard 3060 ("Wagap, in sylvis montium", 1861-1867, st., $\mathrm{K}, \mathrm{P}$ [2 sheets]) is a mixed collection consisting of flowers of Oxera Labill. (Lamiaceae) and leaves of Virotia (G. Gâteblé, pers. comm.). The flowers represent the type material of Oxera merytifolia Guillaumin (G. Gâteblé, pers. comm.; DE KoK \& Mabberley, 1999). Based on their shape and venation, the leaves appear to belong to $V$. azurea although the petiole is longer than in other collections. Because the locality of Wagap is vague, this specimen has been omitted from the distribution map, and it is also omitted from the list of paratypes.

Paratypi. - New Caledonia. Prov. Nord: Amoa, 2056'21"S 165¹1'40"E, 330-340 m, 20.X.2018, fl., Bruy \& Laudereau 1220 (NOU); Povila, 20 $57^{\prime} 21^{\prime \prime S}$ 165'17'29"E, 390-400 m, 20.IV.2019, fl., Bruy E' Laudereau 1281 (NOU); Tchamba, 2100'26"S 165¹4'36"E, 480 m, fr., Gatêblé et al. 449 (NOU); crête entre Haute Amoa et Haute Tchamba, 600 m, 21.VI.1966, fl., MacKee 15159 (NOU, P [2 sheets]); ibid. loco, Expl. Forestière Létocart, [2100'54"S 16514'11"E], 600 m, 22.XI.1967, fl. \& y.fr., MacKee 18031 (NOU, P [2 sheets]); Povila, [2057'36"S 165'19'03"E], 400 m, 13.VI.1974, fl. buds, MacKee 28793 (P); Mt Aoupinié, [21 $\left.11^{\circ} \mathrm{S} 165^{\circ} 16^{\prime} \mathrm{E}\right], 500$ m, 2.XII.1993, buds \& fr., MacKee [leg. Suprin] 46274 (NOU, P); Haute Tchamba, 2100'55"S 165¹5'06"E, 10.XI.2002, fl., Munzinger et al. 1462 (P); Plateau de Tango, pentes du Pic 700 au NW de Palo, [2059'S 165 01'E], 21.X.1981, old fl., Veillon 4651 (NOU, P).

\section{Notes on Virotia francii and V. leptophylla}

The following material was identified by Virot as Macadamia francii ( $\equiv$ Virotia francii) (based on his determinavit labels and the first three sheets were also cited in VIROT, 1968) and is re-determined here as V. leptophylla: MacKee 12654, Farino: forêt Mépéou, Exploitation Forestière Germain (P); MacKee 12655, ibid. loco, rejet de 12654 (P); MacKee [leg. Gay] 15493, ibid. loco, état de jeunesse avancé (P); Veillon 1618, Mt Arago (P). In addition, MacKee 18508 (Massif de Ton-Non, Roches Ouaième, P) was determined by Virot as $M$. francii but is redetermined by us as $V$. vieillardii, a species confined to north-eastern Grande Terre and which has ovate-elliptic leaf blades with quite well-defined areoles and borne on relatively long petioles (up to $10 \mathrm{~cm}$ ). These new determinations have been entered in Sonnerat (2020), where images of the sheets can be seen.

Among the specimens cited above, the field notes of MacKee 12654 described the flowers as "bleu clair à extrémité blanche", and so resembling the flowers of $V$. azurea, although the flowers of $V$. leptophylla are usually white or pale yellow. However, the leaf blades of this MacKee collection are relatively short with comparatively long petioles, hence our determination of this sheet as $V$. leptophylla.

Removal of these collections from Virot's concept of Macadamia francii, together with the description of Virotia azurea, means that $V$. francii is now a morphologically more homogeneous species restricted to ultramafic substrates in southern Grande Terre. Like both V. azurea and V. leptophylla, it commonly has elliptic, obovate-elliptic or rather long, narrow leaves; in V. francii, the petiole is (1-)1.5-6 cm long and the blades $13-43 \times 2.8-7.8 \mathrm{~cm}$, with the base cuneate or narrowly cuneate (to decurrent) and sometimes unequal, and the apex is \pm acute and mucronulate, broadly acute, obtuse or occasionally rounded-retuse; leaves in juvenile plants and regrowth shoots can be slightly larger. As mentioned above, $V$. francii is most easily distinguished by the intramarginal vein that extends from the base of the leaf to the tip. Its immature fruits are beaked, as in $V$. azurea, whereas those of $V$. leptophylla are \pm circular in outline and unbeaked, although sometimes they have a small umbo that develops from the base of the style.

Virotia leptophylla is rather unusual in that it occurs on nonultramafic substrates in central Grande Terre and ultramafic ones in parts of the south, in the Thy valley (several collections; substrate ultramafic or a mosaic including ultramafic), Nord de la Conception (Balansa 2294, type, P; substrate probably ultramafic), and Haute Rivière des Pirogues, Forêt Faux Bon Secours (MacKee 38034, P; substrate ultramafic). As mentioned above, the adult leaves are usually narrowly obovate-elliptic, elliptic, ovate, or sometimes oblanceolate (petioles 1-4.5 cm long; blades $7.5-22.5 \times 2.5-8.5 \mathrm{~cm}$ ), with the base cuneate or narrowly cuneate and the apex obtuse to rounded and often retuse. Leaves from juveniles and small plants that flower in the understorey at c. $4 \mathrm{~m}$ high are usually narrowly ellipticovate (to $27 \times 7 \mathrm{~cm}$ ) with an acute-mucronulate apex and longer petioles (to $7.5 \mathrm{~cm}$ ). Some specimens from the region of La Foa and Canala (McPherson 6387, P; McPherson 6119, P; MacKee $12654, \mathrm{P})$ have somewhat atypical long lanceolate leaves with secondary veins branching nearer the margin, tertiary veins more apparent, and more coriaceous leaf blades. Typical forms and intermediates occur in the same area, so these variants probably do not warrant recognition as a distinct entity.

The collection Tronchet et al. 462 (P) from Mt Görö Até is left unplaced for now. Its pink flowers and relatively short, 
densely flowered inflorescences are reminiscent of $V$. angustifolia (Virot) P.H. Weston \& A.R. Mast but it differs from the latter by its leaf blades, which are less coriaceous and have a rounded, not pointed, apex, and distinct petioles that are $2 \mathrm{~cm}$ long (petioles absent or very short in $V$. angustifolia). The $\mathrm{Mn}$ content of this specimen is modest (1047 ppm), suggesting that the plant was not growing on ultramafic substrate, whereas $V$. angustifolia is a strong Mn hyperaccumulator restricted to the ultramafic substrates of Tiébaghi. Tronchet et al. 462 appears to have a similar ecology to $V$. azurea and was collected within the distribution of $V$. azurea (and possibly $V$. leptophylla), but its pink flowers and rounded leaf apices distinguish it from $V$. azurea, while its long leaf blades $(34 \mathrm{~cm})$ with thicker petioles (2 $\mathrm{mm}$ wide) distinguish it from $V$. leptophylla.

\section{Acknowledgments}

We thank NOU (especially David Bruy) and MO for providing images of herbarium material, the Muséum national d'Histoire naturelle $(\mathrm{P})$ for the loan of material and Florian Jabbour for his assistance at P; Gildas Gâteblé and Christian Laudereau for kindly allowing us to use their photographs and Gildas for providing information about Oxera merytifolia and drawing our attention to the colour of the cotyledons in Virotia azurea; David Bruy for information on architecture; Jérôme Munzinger, Dominique Fleurot and Peter Weston for photographs of other species of Virotia, used to score characters in Table 1; and Andrew Brown for the beautiful drawing. HCFH thanks Odile Poncy for hospitality while visiting P. We also thank Peter Weston for his helpful comments on the original version of the manuscript.

\section{References}

Bachman, S. \& J. Moat (2012). GeoCAT - an open source tool for rapid Red List assessments. Bot. Gard. Conservation Int. J. 9.

BRUY, D. (2018). Diversité, écologie et évolution des plantes monocaules de Nouvelle-Calédonie. Doctoral dissertation, Université de Montpellier, Montpellier.

de Koк, R.P.J. \& D.J. Mabberley (1999). A synopsis of Oxera Labill. (Labiatae). Kew Bull. 54: 265-300.

GeoCAT (2020). Geospatial Conservation Assessment Tool. [http:// geocat.kew.org]

IUCN (2012). IUCN Red List Categories and Criteria: Version 3.1. Ed. 2. IUCN Species Survival Commission, Gland \& Cambridge.

IUCN (2017). Guidelines for Using the IUCN Red List Categories and Criteria: Version 13. Prepared by the IUCN Standards and Petitions Subcommittee. IUCN Species Survival Commission, Gland \& Cambridge.
Jaffre, T. (1979). Accumulation du manganèse par les Protéacées de Nouvelle-Calédonie. Compt. Rend. Acad. Sci. Paris, sér. D, Sci. Nat. 289: 425-428.

Jaffré, T., Y. Pillon, S. Thomine \& S. Merlot (2013). The metal hyperaccumulators from New Caledonia can broaden our understanding of nickel accumulation in plants. Front. Plant Sci. 4: 279.

Johnson, L.A.S. \& B.G. Briggs (1975). On the Proteaceae - the evolution and classification of a southern family. Bot. J. Linn. Soc. 70: 83-182.

Lillie, A.R. \& R.N. Brothers (1970). The geology of New Caledonia. N. Z. J. Geol. Geophys. 13: 145-183.

Mast, A.R., C.L. Willis, E.H. Jones, K.M. Downs \& P.H. Weston (2008). A smaller Macadamia from a more vagile tribe: inference of phylogenetic relationships, divergence times, and diaspore evolution in Macadamia and relatives (tribe Macadamieae; Proteaceae). Amer. J. Bot. 95: 843-870.

Morat, P. (2010). Les botanistes récolteurs en Nouvelle-Calédonie de 1774 à 2005. Adansonia ser. 3, 32: 159-216. DOI: https://doi. org/10.5252/a2010n2a1

Sonnerat (2020). Base de données des collections du Muséum national d'Histoire naturelle. Paris. [http://science.mnhn.fr/ institution/mnhn/collection/p/item/search/form]

Stearn, W.T. (1992). Botanical Latin. Ed. 4. David \& Charles, Newton Abbot.

Van der Ent, A., G. Echevarria, A.J. Pollard \& P.D. Erskine (2019). X-Ray fluorescence ionomics of herbarium collections. Sci. Rep. 9: 4746.

Virot, R. (1956). La végétation canaque. Faculté des Sciences de l'Université de Paris, Paris.

Virot, R. (1968). Protéacées. Fl. Nouvelle-Calédonie et Dépendances 2. Virot, R. (1975). Epacridacées. Fl. Nouvelle-Calédonie et Dépendances 6. Weston, P.H. (1995). Catalepidia. In: McСавтнy, P. (ed.), Fl. Australia 16: 415-416.

Weston, P.H. (2007). Proteaceae. In: Kubitzki, K. (ed.), The families and genera of vascular plants, vol. 9: 364-404. Springer, Berlin.

Weston, P.H. \& N.P. BARKer (2006). A new suprageneric classification of the Proteaceae, with an annotated checklist of genera. Telopea 11: 314-344. 